\title{
Inhibition and adsorption potentials of mild steel corrosion using methanol extract of Gongronema latifoliuim
}

\author{
Chiedozie C. Aralu ${ }^{1}$ Helen O. Chukwuemeka-Okorie² $\cdot$ Kovo G. Akpomie A,4 $^{3,4}$
}

Received: 8 November 2019 / Accepted: 18 December 2020 / Published online: 18 January 2021

(c) The Author(s) 2021

\begin{abstract}
Gongronema latifolium was used as a low-cost green inhibitor for mild steel by applying the weight loss method at 303$323 \mathrm{~K}$. There was a decrease in percentage inhibition with temperature increase and a rise in inhibition efficiency with an increase in the concentration of inhibitor. The obtained results showed that Gongronema latifolium extract of methanol had percentage inhibition efficiencies in the range of 59.06-81.69\%. Corrosion inhibition of mild steel showed a good fit to the Langmuir model compared to the Freundlich and El-Awardy adsorption models. Thermodynamics parameters, such as $E_{\mathrm{a}}$, $Q_{\text {ads }}$ and $\Delta G_{\text {ads }}$ were evaluated and showed that the mechanism of corrosion inhibition of mild steel by methanol extract of Gongronema latifolium was physisorption. The results of this work indicated efficient potentials of the methanol extract of Gongronema latifolium as a low-cost corrosion inhibitor in acidic media for mild steel, which could be applied to reduce corrosion of metals in industries.
\end{abstract}

Keywords Corrosion inhibition · Gongronema latifolium extract · Adsorption

\section{Introduction}

Numerous failures and eventual losses of equipment in the chemical industry have been traced to corrosion processes. However, corrosion inhibitors utilization has been discovered to be a very suitable and efficient option (Quraishi and Singh 2010). Inhibitors used for corrosion are substances able to retard the rate of corrosion when added, by being adsorbed on the surface of the metal through the mechanism of physical or chemical adsorption (Douadi et al. 2014). Naturally occurring substances, especially plant extracts as inhibitors for corrosion of materials, have received attention worldwide as a replacement for synthetic ones, which have several detrimental effects on the environment and human

Chiedozie C. Aralu

edoziearalu@gmail.com

1 Department of Chemistry, Nnamdi Azikiwe University, Awka, Nigeria

2 Department of Chemistry, Michael Okpara University of Agriculture, Umudike, Nigeria

3 Department of Pure and Industrial Chemistry, University of Nigeria, Nsukka, Nigeria

4 Department of Chemistry, University of the Free State, Bloemfontein, South Africa beings (Ebenso et al. 2008). Green corrosion inhibitors are less toxic, easily accessible, less expensive and biodegradable (Eddy et al. 2010). Plant extracts are organic and contain phytochemical compounds (Kristianto et al. 2019). Organic inhibitors are those containing hetero-atoms in their structures, which allows easy adsorption onto the surface of the metal. Sulphur, phosphorus, nitrogen and oxygen are heteroatoms present in their structures which act as adsorption centres (Ebenso et al. 2010). Different plant extracts have been widely reported as effective corrosion inhibitors in various corrosive environments (Umoren et al. 2013; Okafor et al. 2008; Deepa and Selvaraj, 2010; Deng and Li 2012; Eduok et al. 2012). Gongronema latifolium belongs to the family Asclepidiaceae. It is called utaziin in the south-eastern part of Nigeria. Gongronema latifolium is a highly valued vegetable in the south-eastern part of Nigeria because of its nutritional and medicinal properties. The study investigated the inhibition effect of methanol extract of Gongronema latifolium leaf for corrosion of mild steel in hydrochloric acid solution by gravimetric technique. 


\section{Materials and methods}

\section{Material preparation}

Physicochemical characterization of mild steel sheets showed the following chemical compositions by weight (\%): Carbon (0.2), Silicon (0.1), Sulphur (0.01), Phosphorous (0.01), Manganese (0.1) and the balance iron. It was obtained commercially. Mild steel coupons have a $0.12 \mathrm{~cm}$ in thickness and were manually cut in dimension into $4 \times 3 \mathrm{~cm}$. A hole was drilled for suspension in the acid at the edge of each coupon. This was followed by polishing the coupons, then degreased by adding absolute ethanol, then acetone aided drying before storage in desiccators for use in the experiment. A solution of $0.5 \mathrm{M}$ hydrochloric acid was prepared from analytical grade hydrochloric acid was used as the corrodent for the experiment.

\section{Preparation of Gongronema latifolium methanol leaf extract}

The leaves were dried and blended into powdered form. These were soxhlet extracted using methanol. The solutions were evaporated at $65{ }^{\circ} \mathrm{C}$ to remove methanol. The stock solution was diluted with $0.5 \mathrm{M} \mathrm{HCl}$ solution to obtain inhibitor solutions of $0.1-0.5 \% \mathrm{w} / \mathrm{v}$ concentrations. This leaf extract was subjected to phytochemical analysis.

\section{Gravimetric method}

The work was done using different temperatures of 303, 313 and $323 \mathrm{~K}$ using 250-ml beakers. Weighed mild steel coupons $(4 \times 3 \times 0.12 \mathrm{~cm})$ with threads were dipped into a $250 \mathrm{ml}$ beaker containing $0.5 \mathrm{M} \mathrm{HCl}$ in a water bath. Mild steel coupons were retrieved at $24 \mathrm{~h}$ intervals for 5 days. They were scrubbed with a brush in ethanol, dried in acetone and reweighed. The experimental work was repeated with different concentrations of inhibitor in $0.5 \mathrm{M} \mathrm{HCl}$. Experiment were performed twice to ensure accuracy, and the average values for the 5 days were used. From the change in the weight loss of coupons, the rate of corrosion was evaluated using the equation (Eddy et al. 2010; Odewole et al. 2021):

$C=\frac{k \times \Delta W}{A \times t \times D}$

where $\Delta W$ is the loss in weight in milligram, $A$ shows exposed surface area of the coupons, $k$, the rate constant, $D$ is the density of mild steel, $t$ is the time of exposure of metal in hours and $C$ represent the rate of corrosion $(\mathrm{mm} / \mathrm{yr})$.

The percentage inhibition was extrapolated by applying the following using the:

$\mathrm{I} . \mathrm{E} \%=\frac{W-W_{i}}{W} \times 100$

where $W_{i}$ and $W$ represent the measured weight loss of the steel in inhibited and uninhibited solutions, respectively.

The following equation was utilized to calculate the extent of surface coverage:

$\theta=\frac{W_{i}-W}{W_{i}}$

\section{Results and discussion}

\section{Phytochemical analysis}

It is observed from Table 1 that methanol extract of Gongronema latifoilum contains phytochemical constituents reported as good corrosion inhibitors (Eddy et al. 2010). The corrosion inhibition of mild steel by methanol extract of Gongronema latifolium was as a result of complex chemical compositions of some phytochemical constituents that contain hetero-atoms that form chemical bonds between the iron in the mild steel and the extract. Normally, suitable effective

Table 1 Phytochemicals of Gongronema latifolium

\begin{tabular}{ll}
\hline Parameters & Presence \\
\hline Alkaloids & + \\
Flavanoid & ++ \\
Reducing Sugars & - \\
Tannins & ++ \\
Phlobatannins & + \\
Proteins & + \\
Amino acid & + \\
Resins & ++ \\
Saponins & ++ \\
Glycosides & - \\
Cardiac glycosides & ++ \\
Carbohydrates & ++ \\
Terpenoid & ++ \\
Triterpenes & ++ \\
Steroids & ++ \\
Quinones & +++ \\
Anthraquinones & - \\
Phenols & + \\
Anthracene & - \\
\hline += Trace amount,,++ Moder- \\
ate amount, $+++=$ Appreciable \\
amount, - Abensence
\end{tabular}


Fig. 1 Weight loss variation for Gongronema latifolium at different temperatures in $0.5 \mathrm{M}$ $\mathrm{HCl}$

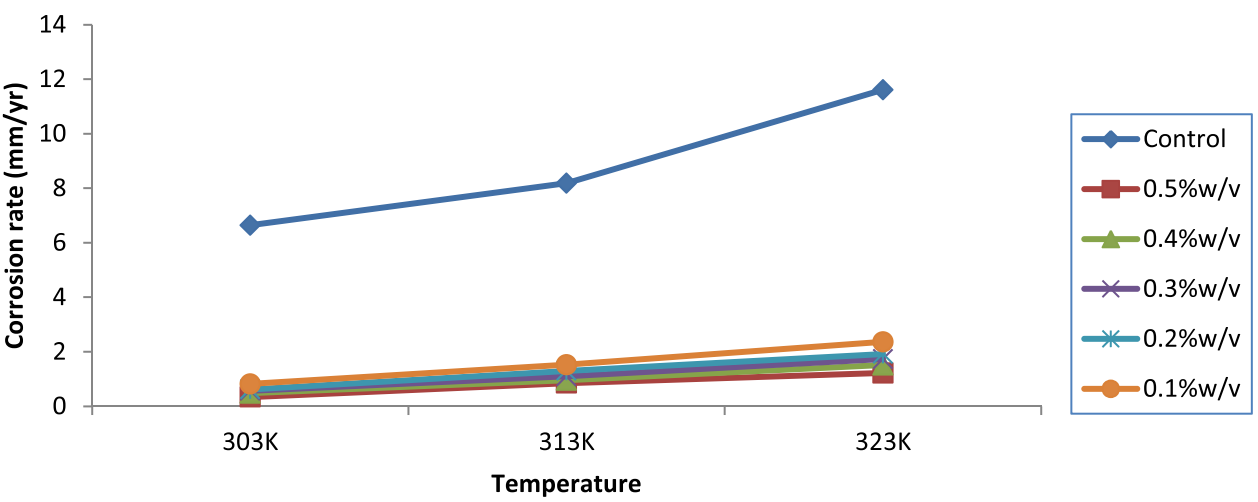

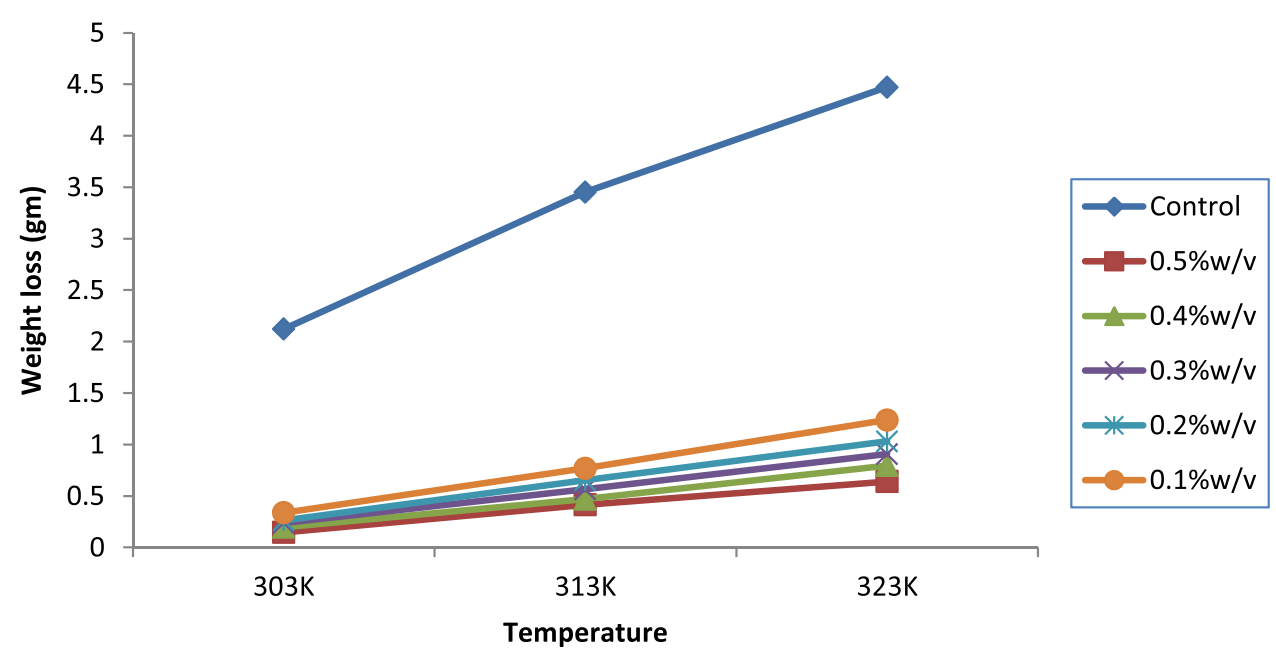

Fig. 2 Corrosion rates of Gongronema latifolium obtained by gravimetric method at different temperatures organic compounds used for corrosion inhibition usually contain hetero-atoms like phosphorous, sulphur, oxygen and nitrogen (Shukla and Quraishi 2009; Sapra et al. 2008). This is due to the ability of the hetero-atoms lone pair of electrons to form a protective film on metal surfaces thereby decreasing the rate of corrosion (Barouni et al. 2014; Li et al. 2009). The results showed the presence of these phytochemicals containing hetero-atoms which are responsible for the inhibition efficiency. This suggests good potentials of the extract of Gongronema latifoilum as a corrosion inhibitor.

\section{Weight loss evaluation}

Figure 1 represents the weight loss against temperature for mild steel at temperatures 30,40 and $50{ }^{\circ} \mathrm{C}$. An increase in extract concentration reduced the weight loss while an increase in temperature increased the mild steel weight loss. Corrosion rate plot against inhibitor concentration for mild steel corrosion in $0.5 \mathrm{M} \mathrm{HCl}$ at various temperatures is shown in Fig. 2. An increase in the concentration of extract reduced the corrosion rate while the increase in temperature increased the corrosion rate. Besides, an increase in temperature increased the susceptibility of the
Table 2 Inhibition efficiency $(I \%)$ in different concentration of Gongronema latifolium leaf methanol extract

\begin{tabular}{llcl}
\hline $\begin{array}{l}\text { Inhibitor concentration of } \\
\text { GL }(\% \text { w/v })\end{array}$ & \multicolumn{3}{l}{ Inhibition efficiency $(\%)$} \\
\cline { 2 - 4 } & $303 \mathrm{~K}$ & $313 \mathrm{~K}$ & $323 \mathrm{~K}$ \\
\hline 0.1 & 63.14 & 59.06 & 56.75 \\
0.2 & 69.25 & 64.57 & 62.87 \\
0.3 & 72.49 & 70.13 & 68.17 \\
0.4 & 78.35 & 76.22 & 72.51 \\
0.5 & 81.69 & 78.74 & 77.47 \\
\hline
\end{tabular}

metal to corrosion (James et al. 2007). Table 2 showed inhibition efficiency variation against different extract concentration of mild steel in $0.5 \mathrm{M} \mathrm{HCl}$ at the various temperatures studied. An increase in extract concentration increased the inhibition efficiency while temperature increase reduced the efficiency of inhibition. Decreased inhibition efficiency at high temperatures was due to the increase in kinetic energy of the extracts, which makes adsorption between the extract and mild steel insufficient at the binding sites (Umoren et al. 2006). 


\section{Thermodynamics studies}

The temperature effect on the corrosion rate of mild steel in a solution of $\mathrm{HCl}$ was studied using the following equation (Odiongenyi et al. 2015)

$\log \frac{\mathrm{CR}_{2}}{\mathrm{CR}_{1}}=\frac{E_{\mathrm{a}}}{2.303 R}\left(\frac{1}{T_{1}}-\frac{1}{T_{2}}\right)$

$\mathrm{CR}_{1}$ and $\mathrm{CR}_{2}$ represents the corrosion rates at $T_{1}$ and $T_{2}$, respectively, Activation energy was represented with $E_{\text {a }}$ and Molar gas constant was represented with $R$ which is $\left(8.314 \mathrm{JK}^{-1} \mathrm{~mol}^{-1}\right)$

The heat of adsorption was determined using the equation (Ebenso et al. 2008).

$Q_{\mathrm{ads}}=2.303 R\left[\log \left(\frac{\theta_{2}}{1-\theta_{2}}\right)-\log \left(\frac{\theta_{1}}{1-\theta_{1}}\right)\right] \frac{T_{1} \times T_{2}}{T_{2}-T_{1}}$

Table 3 shows the results of $E_{\mathrm{a}}$ and $\Delta Q_{\text {ads }}$ at various inhibitor concentrations. Activation energy results showed that the inhibited system values were greater than the uninhibited

Table 3 Thermodynamics adsorption parameters of Gongronema latifolium methanol extract

\begin{tabular}{lll}
\hline $\begin{array}{l}\text { Concentration of inhibition } \\
(\% \mathrm{w} / \mathrm{v})\end{array}$ & $E_{\mathrm{a}}(\mathrm{kJ} / \mathrm{mol})$ & $Q_{\text {ads }}(\mathrm{KJ} / \mathrm{mol})$ \\
\hline Control & 17.34 & - \\
0.1 & 51.32 & -13.26 \\
0.2 & 61.57 & -14.29 \\
0.3 & 54.67 & -11.62 \\
0.4 & 56.77 & -8.92 \\
0.5 & 76.19 & -15.31 \\
\hline
\end{tabular}

system. $E_{\mathrm{a}}$ values lower than $80 \mathrm{~kJ} / \mathrm{mol}$ is consistent with physisorption, while $E_{\mathrm{a}}$ values greater than $80 \mathrm{~kJ} / \mathrm{mol}$ followed chemisorption (Ebenso et al. 2010). The obtained results showed that the adsorption followed the physical adsorption mechanism. Negative values of $\Delta Q_{\mathrm{ads}}$ showed that the reaction was exothermic (Rao and Khan 2017; Ribas et al. 2020).

\section{Adsorption considerations}

The extent of surface coverage evaluations was utilized for the determination of Freundlich, Langmuir, and El-Awardy isotherms. Langmuir adsorption isotherm is expressed using the relationship (Bilgic and Caliskan 2001).

$C / \theta=C+1 / K$

Taking the $\log$ of both sides of the equation yields Eq. 7

$\log C / \theta=\log C-\log K$

where the concentration of the inhibitor is represented as $C$, the degree of surface coverage is $\theta$ is and the equilibrium constant of adsorption is represented as $K$. The graph of log $C / \theta$ against $\log C$ in Fig. 3 gave linear plots and a good correlation coefficient indicated strong support to Langmuir isotherm. Langmuir isotherm parameters are shown in Table 4. The slopes obtained are close to 1 which showed that the extract adsorption on the metal was monolayer adsorption and that no interaction existed between extract and mild steel (Ashassi-Sorkhabi et al. 2004; Ebenso et al. 2008; Dawodu et al. 2020; Kamga 2019).

Freundlich adsorption isotherm of Gongronema latifoilum extracts on mild steel surface was given by Eqs. 8 (Adejo et al. 2013).

Fig. 3 Adsorption of Langmuir isotherm plot of Gongronema latifolium on the surface of mild steel at different temperatures

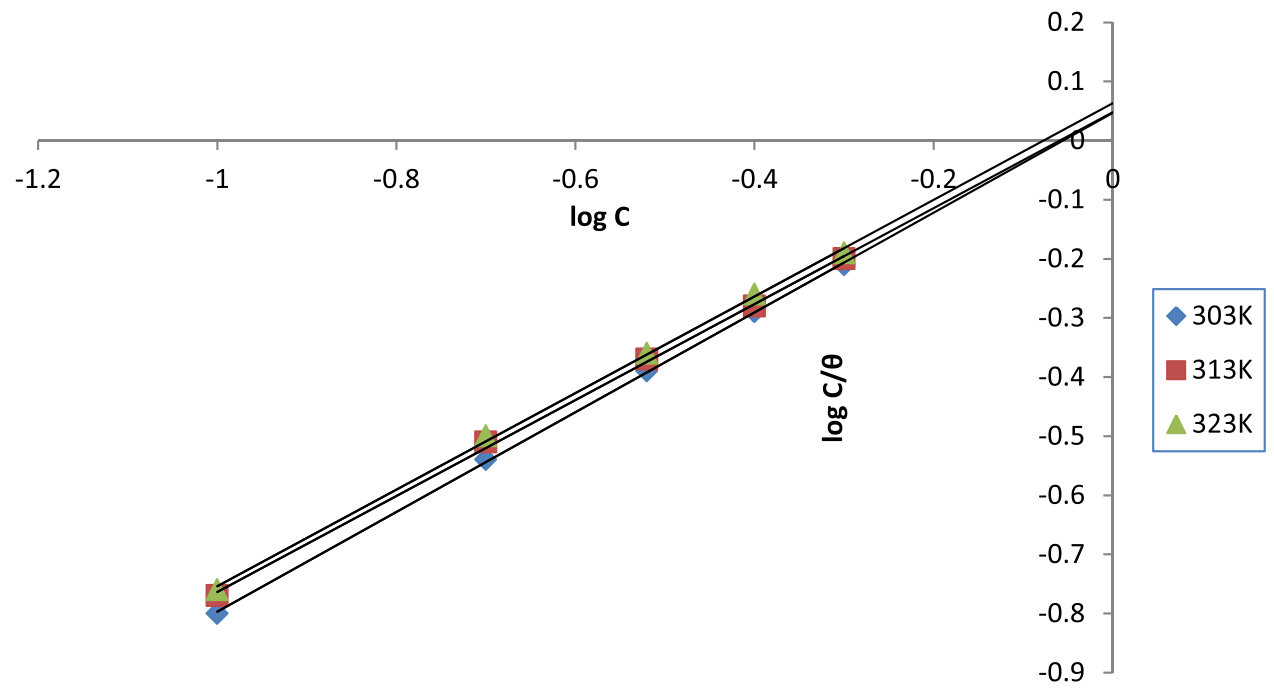


Table 4 Gongronema latifolium adsorption parameters on the mild steel surface

\begin{tabular}{llrll}
\hline Isotherm & Temp $\left({ }^{\circ} \mathrm{C}\right)$ & \multicolumn{1}{c}{$K_{\text {ads }}$} & $\Delta G_{\text {ads }}(\mathrm{kJ} / \mathrm{mol})$ & $R^{2}$ \\
\hline Langmuir & 30 & 0.90 & -9.85 & 0.9998 \\
& 40 & 0.90 & -10.18 & 0.9990 \\
Freundlich & 30 & 0.86 & -10.38 & 0.9990 \\
& 40 & 89.13 & -21.43 & 0.9783 \\
& 50 & 89.64 & -22.16 & 0.9603 \\
El-Awardy & 30 & 87.00 & -22.78 & 0.9840 \\
& 40 & 5.84 & -14.57 & 0.9182 \\
& 50 & 5.28 & -14.78 & 0.9108 \\
& & 4.60 & -14.89 & 0.9583 \\
\hline
\end{tabular}

$\frac{x}{m}=k c^{1 / n}$

Taking again the logarithm of both sides of the equation yields Eq. 9: $\log \frac{x}{m}=\log K+\frac{1}{n} \log C$

$\frac{x}{m}$ represents the inhibitor efficiency, $n$ and $k$ are constant. $\frac{1}{n}$ represents the slope and $\log K$ represents the intercept. Freundlich adsorption isotherm parameters were established by plotting $\log$ inhibition efficiency (I.E \%) versus $\log C$ in Fig. 4 which gives a straight line graph produced that followed Freundlich adsorption (Adejo et al. 2012). The parameters of Freundlich adsorption isotherm are presented in Table 4. $R^{2}$ values are close to 1 , which followed Freundlich adsorption.

El-Awardy isotherm, which can be written as (Shukla and Ebenso 2011; Adejo et al. 2013).

$\log \left(\frac{\theta}{1-\theta}\right)=\log k+y \log C$

where $C$ is the inhibitor concentration, $\theta$ represents the surface coverage degree, the equilibrium constant is denoted as $K$ and $y$ is the number of molecules in a given site. ElAwardy adsorption parameters were derived by plotting log $(\theta / 1-\theta)$ against $\log C$ in Fig. 5 which produced straight
Fig. 4 Adsorption of Freundlich isotherm plot of Gongronema latifolium on the surface of mild steel at different temperatures
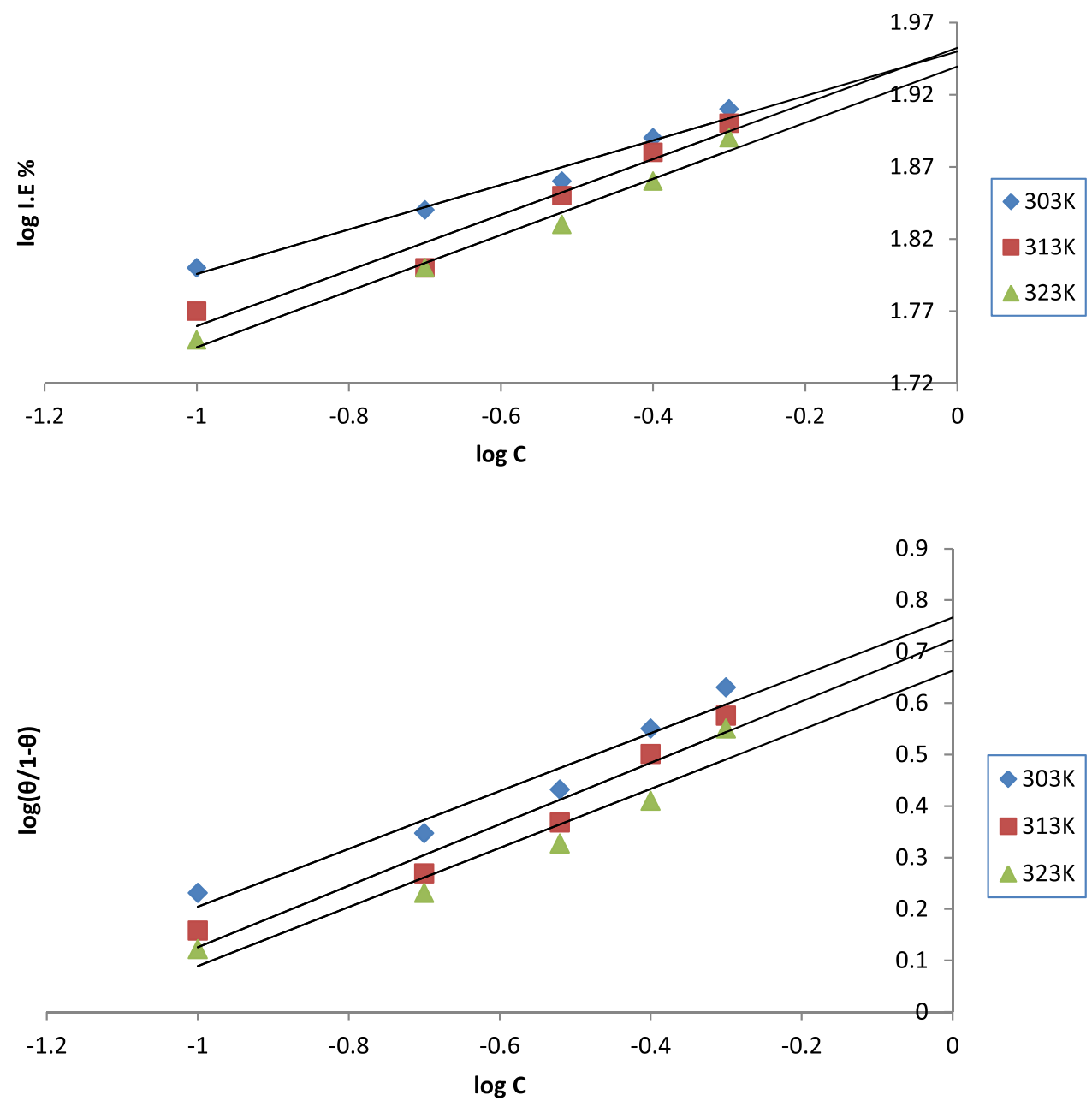

Fig. 5 Adsorption of ElAwardy isotherm of the extract of Gongronema latifolium on mild steel surface at different temperatures 
lines with a good correlation coefficient which showed that the experimental data fits the isotherm (Shukla and Ebenso 2011; Adejo et al. 2012). Values of 1/y which are above 1 showed the extract indicates that the inhibitor takes more than one active site on the surface of the metal, which implies that more than one water molecule was replaced in the course of the inhibition process (Ebenso et al. 2010).

$K_{\text {ads }}$ represents the strength of adsorption between adsorbate and adsorbent. Calculated results of $K_{\text {ads }}$ obtained from the plots decreased with temperature rise. It was attributed that at higher temperatures, the adsorbing molecules that interact with the metal surface were weak, which justified the mechanism of physisorption (Odiongenyi et al. 2015).

$=-2.303 R T \log (55.5 \mathrm{~K})$

Gas constant was represented with $R$, the temperature was represented by $T$, equilibrium constant was represented by $K$, and 55.5 represents the molar heat of water adsorption. $K$ values from the intercept of Langmuir, Freundlich and ElAwardy models were used to evaluate $\Delta G_{\text {ads }}$ based on Eq. 11 and the result shown in Table 4 . The $\Delta G_{\text {ads }}$ values for the corrosion inhibition were negative which showed a feasible and spontaneous inhibition process. Also, values of $\Delta G_{\text {ads }}$ lower than $40 \mathrm{~kJ} / \mathrm{mol}$ depicts chemisorptions, however, our values obtained were lower which suggested the mechanism of adsorption followed physisorption.

\section{Conclusion}

Gongronema latifolium methanol extract was utilized as a green corrosion inhibitor for mild steel in aqueous media. The Gongronema latifolium extract was found to be composed of several phytochemical components desirable for efficient corrosion inhibition. The corrosion inhibition efficiency of the plant extract was increased as the inhibitor concentration increased and decreased with temperature increase. The corrosion inhibition efficiency of $56.75-81.69 \%$ was obtained for the plant extract for the mild steel, which indicated efficient potentials of the methanolic plant extract. The adsorption of Gongronema latifolium extract obeyed the Langmuir adsorption model with $R^{2}>0.99$, though good fits were also observed for the Freundlich and El-Awardy adsorption isotherms. The adsorption thermodynamics of the inhibition process gave activation energies in the range $17.34-76.19 \mathrm{~kJ} / \mathrm{mol}$ indicating a physical adsorption mechanism of corrosion. The results of this study showed the potential of Gongronema latifolium extract as a low-cost green inhibitor of mild steel which could be utilized in industries to prevent corrosion.

Funding The author(s) received no specific funding for this work.

\section{Compliance with ethical standards}

Conflict of interest The authors declare no conflict of interest.

Open Access This article is licensed under a Creative Commons Attribution 4.0 International License, which permits use, sharing, adaptation, distribution and reproduction in any medium or format, as long as you give appropriate credit to the original author(s) and the source, provide a link to the Creative Commons licence, and indicate if changes were made. The images or other third party material in this article are included in the article's Creative Commons licence, unless indicated otherwise in a credit line to the material. If material is not included in the article's Creative Commons licence and your intended use is not permitted by statutory regulation or exceeds the permitted use, you will need to obtain permission directly from the copyright holder. To view a copy of this licence, visit http://creativecommons.org/licenses/by/4.0/.

\section{References}

Adejo SO, Ekwenchi MM, Momoh F, Odiniya E (2012) Adsorption characterization of ethanol extract of leaves of Portulaca oleracea as green corrosion inhibitor for corrosion of mild steel in sulphuric acid medium. Int J Mod Chem 1(3):125-134

Adejo SO, Yiase SG, Ahile UJ, Tyohemba TG, Gbertyo JA (2013) Inhibitory effect and adsorption parameters of extract of leaves of Portulaca oleracea of corrosion of aluminium in $\mathrm{H}_{2} \mathrm{SO}_{4}$ solution. Arch Appl Sci Res 5(1):25-32

Ashassi-Sorkhabi H, Majidi MR, Seyyedi K (2004) Investigation of inhibition effect of some amino acids against steel corrosion in $\mathrm{HCl}$ solution. Appl Surf Sci 225:176-185

Barouni K, Kassale A, Albourine A, Jbara O, Hammouti B, Bazzi L (2014) Amino acids as corrosion inhibitors for copper in nitric acid medium: experimental and theoretical study. J Mater Environ Sci 5(2):456-463

Bilgic S, Caliskan N (2001) An Investigation of some schiff bases as corrosion inhibitors for austenite chromium-nickel steel in $\mathrm{H}_{2} \mathrm{SO}_{4}$. J Appl Electrochem 31(1):79-83

Dawodu FA, Akpan BM, Akpomie KG (2020) Sequestered capture and desorption of hexavalent chromium from solution and textile wastewater onto low cost Heinsia crinita seed coat biomass. Appl Water Sci 10:32

Deepa Rani P, Selvaraj S (2010) Inhibitive and adsorption properties of Punica granatum extract on brass in acid media. J Phytol 2(11):58-64

Deng S, Li X (2012) Inhibition by Ginkgo leaves extract of the corrosion of steel in $\mathrm{HCl}$ and $\mathrm{H}_{2} \mathrm{SO}_{4}$ solutions. Corros Sci 55:407-415

Douadi T, Issaadi S, Chafaa S (2014) Adsorption and corrosion inhibition of new synthesized thiophene Schiff base on mild steel X52 in $\mathrm{HCl}$ and $\mathrm{H}_{2} \mathrm{SO}_{4}$ solutions. Corros Sci 79:50-58

Ebenso EE, Eddy NO, Odiongenyi AO (2008) Corrosion inhibitive properties and adsorption behavior of ethanol extract of Piper guinensisas a green corrosion inhibitor for mild steel in $\mathrm{H}_{2} \mathrm{SO}_{4}$. Afr J Pure Appl Sci 4(11):107-115

Ebenso EE, Murulana LC, Obot IB (2010) Quinoline and its derivatives as effective corrosion inhibitors for mild steel in acidic medium. Int J Electrochem Sci 5:1574-1586

Eddy NO, Ebenso EE, Ibok UJ (2010) Adsorption, synergistic, inhibitive effect and quantum chemical studies on ampicillin and halides for the corrosion of mild steel. J Appl Electrochem 40:445-456

Eduok U, Umoren S, Udoh A (2012) Synergistic inhibition effects between leaves and stem extracts of Sidaacuta and iodide ion 
for mild steel corrosion in $1 \mathrm{M} \mathrm{H}_{2} \mathrm{SO}_{4}$ solutions. Arab J Chem 5(3):325-337

James AO, Oforka NC, Abiola OK (2007) Inhibition of acid corrosion of mild steel by pyridoxal and pyridoxol hydrochlorides. Int $\mathbf{J}$ Electrochem Sci 2:278-284

Kamga FT (2019) Modeling adsorption mechanism of paraquat onto Ayous (Triplochiton scleroxylon) wood sawdust. Appl Water Sci 9:1

Kristianto H, Rahman H, Prasetyo S, Sugih AK (2019) Removal of congo red aqueous solution using Leucaena leucocephala seeds extract as natural coagulants. Appl Water Sci 9:88

Li XH, Deng SD, Fu H, Mu GN (2009) Inhibition effect of 6-benzylaminopurine on the corrosion of cold rolled steel in $\mathrm{H}_{2} \mathrm{SO}_{4}$ solution. Corros Sci 51:620-634

Odewole OA, Ibeji CU, Oluwasola HO, Oyeneyin OE, Akpomie KG, Ugwu CM, Ugwu CG, Bakare TE (2021) Synthesis and anti-corrosive potential of Schiff bases derived 4-nitrocinnamaldehyde for mild steel in $\mathrm{HCl}$ medium: experimental and DFT studies. J Mol Struct 1223:129214

Odiongenyi AO, Enengedi IS, Ukpong EJ, Ibok I (2015) Inhibition of the corrosion of zinc in $0.1 \mathrm{M} \mathrm{HCl}$ by ethanol extract of honey. Int J Chem Mater Environ Res 2(1):16-25

Okafor PC, Ikpi ME, Uwah IE, Ebenso EE, Ekpe UJ, Umoren SA (2008) Inhibitory action of Phyllanthu samaras extracts on the corrosion of mild steel in acidic media. Corros Sci 50:2310-2317

Quraishi MA, Singh AK (2010) Piroxicam; A novel corrosion inhibitor for mild steel corrosion in $\mathrm{HCl}$ acid solution. J Mater Environ Sci 2:101-110
Rao RAK, Khan U (2017) Adsorption studies of Cu(II) on Boston fern (Nephrolepis exaltata Schott cv. Bostoniensis) leaves. Appl Water Sci 7:2051-2061

Ribas MC, de Franco MAE, Adebayo MA, Lima EC, Parkes GMB, Feris LA (2020) Adsorption of Procion Red MX-5B dye from aqueous solution using homemade peach and commercial activated carbons. Appl Water Sci 10:154

Sapra PK, Singh S, Prakash S (2008) Evaluation of detonation gum sprayed titanic coatings. Int J Surf Eng 2(5):400-408

Shukla SK, Ebenso EE (2011) Corrosion inhibition, adsorption behavior and thermodynamic properties of streptomycin on mild steel in hydrochloric acid medium. Int J Electrochem Sci 6:3277-3291

Shukla SK, Quraishi MA (2009) Ceftriaxone: a novel corrosion inhibitor for mild steel in hydrochloric acid. J Appl Electrochem 39:1517-1523

Umoren SA, Ogbobe O, Ebenso EE, Ekpe UJ (2006) Effect of halide ions on the corrosion inhibition of mild steel in acidic medium using polyvinyl alcohol. Pigment Resin Technol 35:284-292

Umoren SA, Gasem ZM, Obot IB (2013) Natural products for materials protection: inhibition of mild steel corrosion by date palm seed extracts in acid media. Ind Eng Chem Res 52:14855-14865

Publisher's Note Springer Nature remains neutral with regard to jurisdictional claims in published maps and institutional affiliations. 